\title{
Supported Chiral Mo-Based Complexes as Efficient Catalysts for Enantioselective Olefin Metathesis
}

\author{
Sarah J. Dolman," Kai C. Hultzsch," Frédéric Pezet," Xin Teng, \\ Amir H. Hoveyda ${ }^{*}, \square$ and Richard R. Schrock ${ }^{\star}, \#$ \\ Department of Chemistry, Massachusetts Institute of Technology \\ Cambridge, Massachusetts 02139 \\ Department of Chemistry, Merkert Chemistry Center, Boston College
}

Chestnut Hill, Massachusetts 02467

\section{SUPPORTING INFORMATION}

General. ${ }^{1} \mathrm{H}$ NMR spectra were recorded on Varian VXR $500(500 \mathrm{MHz})$ or Unity 300 (300 MHz) spectrophotometers. Chemical shifts are reported in ppm from tetramethylsilane with the solvent resonance as the internal standard $\left(\mathrm{C}_{6} \mathrm{D}_{6}: \square 7.16\right.$, $\mathrm{CDCl}_{3}$ : 7.26). Data are reported as follows: chemical shift, multiplicity ( $\mathrm{s}=$ singlet, $\mathrm{d}=$ doublet, $\mathrm{t}=$ triplet, $\mathrm{q}=$ quartet, $\mathrm{br}=$ broad, $\mathrm{m}=$ multiplet $)$, coupling constants $(\mathrm{Hz})$, integration, and assignment. ${ }^{13} \mathrm{C}$ NMR spectra were recorded on Varian VXR 500, (125 $\mathrm{MHz})$ Unity $300(75 \mathrm{MHz})$ or Bruker DPX $400(100 \mathrm{MHz})$ spectrophotometer with complete proton decoupling. Chemical shifts are reported in ppm from tetramethylsilane with the solvent resonance as the internal standard $\left(\mathrm{C}_{6} \mathrm{D}_{6}: \square 128.39, \mathrm{CDCl}_{3}\right.$ : $\mathrm{7}$ 77.7). High-resolution mass spectrometry was performed at the Massachusetts Institute of Technology, Department of Chemistry Instrumentation Facility (Cambridge, MA) or at the University of Illinois Mass Spectrometry Laboratories (Urbana-Champaign, IL). Infrared (IR) spectra were recorded on ThermoNicolet Avatar 360 spectrophotometer, $\square_{\max }$ in $\mathrm{cm}^{-1}$. Bands were characterized as broad (br), strong (s), medium (m), and weak (w). Enantiomer ratios were determined by chiral HPLC (Chiral Technologies Chiralpak AS $(4.6 \mathrm{~mm} \square \times 250 \mathrm{~mm})$, Chiralcel OJ $(4.6 \mathrm{~mm} \square \times 250 \mathrm{~mm})$ or Chiralcel OD $(4.6 \mathrm{~mm}$ $\square \times 250 \mathrm{~mm}$ )) or chiral GLC (CDGTA, CD-BPH, and प-dex) in comparison with authentic racemic materials. Elemental-analysis for trace Mo-content (ICP-MS) was performed by H. Kolbe Microanalytics Laboratory (Mülheim an der Ruhr, Germany) or Robertson-Microlit (Madison, NJ).

All reactions were conduction in oven- $\left(135^{\circ} \mathrm{C}\right)$ or flame-dried glassware under an inert atmosphere of dry $\mathrm{N}_{2}$. All metathesis substrates were dried by storage over $4 \AA$ molecular sieves under a $\mathrm{N}_{2}$ atmosphere for a minimum of 12 hours prior to use. Handling of all Mo complexes was performed in a dry box. $\mathrm{Et}_{2} \mathrm{O}$, toluene, and pentane were purged with dry $\mathrm{N}_{2}$ and then passed through an activated alumina column or distilled from sodium/benzophenone ketyl. All reagents were used as received from Aldrich Chemical Co., Lancaster Synthesis, or Strem Chemicals, Inc. unless otherwise stated. Chiral Mo complexes were prepared according to previously reported 
procedures. ${ }^{1-3}$ All substrates and products have been described previously in the literature. $^{4-16}$

Polystyrene-supported chiral Mo complex 6. A suspension of potassium hexamethyldisilazide $(82 \mathrm{mg}, 0.39 \mathrm{mmol})$ and the appropriate polystyrene-supported ligand $(1 \mathrm{~g}, 0.13 \mathrm{mmol} / \mathrm{g})$ in THF $(100 \mathrm{~mL})$ was agitated by slow rotation for $24 \mathrm{~h}$, then filtered, washed with THF $(4 \times 8 \mathrm{~mL})$ and ether $(3 \times 7 \mathrm{~mL})$. The resulting product was dried in vacuo to an orange-brown solid. To this solid was added THF $(20 \mathrm{~mL})$ and the requisite Mo triflate $\left(\left(\mathrm{Ar}_{\mathrm{Cl}} \mathrm{N}\right) \mathrm{Mo}(\mathrm{CH} t \mathrm{Bu})(\mathrm{OTf})_{2} \cdot \mathrm{dme}\right)(93 \mathrm{mg}, 0.13 \mathrm{mmol})$; the suspension was agitated another 24 hours. The resulting product was filtered, washed with THF (3 x $20 \mathrm{~mL}$, only slightly yellow washings $)$ and pentane $(3 \times 20 \mathrm{~mL})$ and dried in vacuo to afford $1.04 \mathrm{~g}$ of a brown powder. Anal. Calcd $1.20 \% \mathrm{Mo}$; Found: $0.95 \% \mathrm{Mo}$; $0.106 \mathrm{mmol} / \mathrm{g}, 79 \%$ loading (Kolbe).

Polystyrene-supported chiral Mo complex 7. A suspension of potassium hexamethyldisilazide ( $82 \mathrm{mg}, 0.39 \mathrm{mmol}$ ) and the appropriate polystyrene-supported ligand $(1 \mathrm{~g}, 0.13 \mathrm{mmol} / \mathrm{g})$ in THF $(100 \mathrm{~mL})$ was agitated by slow rotation for $24 \mathrm{~h}$. Subsequent filtration of solids, washing with THF $(3 \times 5 \mathrm{~mL})$ and drying of the resulting solid in vacuo afforded an orange-brown solid. To this solid was added THF $(15 \mathrm{~mL})$ and the requisite $\mathrm{Mo}$ triflate $\left((\mathrm{AdN}) \mathrm{Mo}\left(\mathrm{CHCMe}_{2} \mathrm{Ph}\right)(\mathrm{OTf})_{2} \bullet \mathrm{dme}\right)(100 \mathrm{mg}, 0.13 \mathrm{mmol})$; the resulting suspension was agitated for an additional $24 \mathrm{~h}$. The resulting product was filtered, washed with THF ( $3 \times 15 \mathrm{~mL}$, only slightly yellow washings) and pentane ( 4 × 5 $\mathrm{mL}$ ) and dried in vacuo to afford $1.0 \mathrm{~g}$ of a brown powder. Anal. Calcd $1.25 \% \mathrm{Mo}$; Found: $1.18 \%$ Mo; $0.123 \mathrm{mmol} / \mathrm{g}, 95 \%$ loading (Kolbe).

Representative ARCM with supported chiral complex 6. A vial was charged with amine triene 10 (30 mg, $106 \square \mathrm{mol})$ and $\mathbf{6}(50 \mathrm{mg}, 5.3 \square \mathrm{mol})$ in benzene. After 18 hours, ${ }^{1} \mathrm{H}$ NMR of an aliquot indicated the reaction to be at $75 \%$ conversion, ${ }^{8}$ and it was filtered over celite, washing with pentane. The crude material was concentrated in vacuo, analyzed by HPLC and a small sample sent for ICP-MS analysis to determine residual metal content.

Representative Asymmetric Olefin Metathesis Transformation with 7. A vial was charged with benzyl-norbornylether $16,(20.7 \mathrm{mg}, 103 \square \mathrm{mol})$ allyl-pinacolborate, (17.3 $\mathrm{mg}, 103 \square \mathrm{mol}$ ) and 7 (47 mg, $5.2 \square \mathrm{mol})$ in benzene. After $3 \mathrm{~h}$, analysis of the ${ }^{1} \mathrm{H} \mathrm{NMR}$ spectrum of an aliquot indicated the reaction to be complete. The resulting mixture was filtered over celite and washed with pentane. Removal of volatiles in vacuo afforded pure 17, as judged by analysis of the ${ }^{1} \mathrm{H}$ NMR spectrum. ${ }^{10}$

Diiodide 24 and 3,3'-bis-(2,4,6-triisopropylphenyl)-2,2'-dimethoxy-1,1'-binapthyl were prepared as previously described. ${ }^{12}$

Dibromide 25. A solution of bromine $(60 \square \mathrm{L}, 1.1 \mathrm{mmol})$ in methylene chloride $(2 \mathrm{~mL})$ cooled to ${ }^{\circ} \mathrm{C}$ was added dropwise to a methylene chloride solution of 3,3'-bis- $(2,4,6$ triisopropylphenyl)-2,2'-dimethoxy-1,1'-binapthyl (360 $\mathrm{mg}, 0.5 \mathrm{mmol})$. After $5 \mathrm{~h}$ at 0 ${ }^{\circ} \mathrm{C}$, the reaction was quenched by the addition of an aqueous solution of $\mathrm{NaHSO}_{3}(10 \%$, 
$5 \mathrm{~mL}$ ). The organic phase was separated, washed with water and brine and dried over anhydrous $\mathrm{MgSO}_{4}$. The resulting yellow foam was purified by column chromatography on silica, eluting with hexane and methylene chloride (9:1) to afford a white foam (368 mg, $0.42 \mathrm{mmol}, 84 \%$ yield). ${ }^{1} \mathrm{H}$ NMR (300 $\left.\mathrm{MHz}, \mathrm{CDCl}_{3}\right): \square 7.98$ (d, J = $\left.2.0 \mathrm{~Hz}, 2 \mathrm{H}\right)$ $7.65(\mathrm{~s}, 2 \mathrm{H}) 7.36(\mathrm{dd}, \mathrm{J}=9.0 \mathrm{~Hz}, \mathrm{~J}=2.0 \mathrm{~Hz}, 2 \mathrm{H}) 7.14(\mathrm{~d}, \mathrm{~J}=9.0 \mathrm{~Hz}, 2 \mathrm{H}) 7.08$ (d, J = 4.8 $\mathrm{Hz}, 4 \mathrm{H}) 3.05$ (s, 6H) 2.94 (septet, J =6.9 Hz, 2H) 2.72 (septet, J =6.9 Hz, 4H) 1.30 (d, J $=6.9 \mathrm{~Hz}, 12 \mathrm{H}) 1.24(\mathrm{~d}, \mathrm{~J}=6.9 \mathrm{~Hz}, 12 \mathrm{H}) 1.18(\mathrm{~d}, \mathrm{~J}=6.9 \mathrm{~Hz}, 6 \mathrm{H}) 1.16(\mathrm{~d}, \mathrm{~J}=6.9 \mathrm{~Hz}$, $6 \mathrm{H}) 1.10(\mathrm{~d}, \mathrm{~J}=6.9 \mathrm{~Hz}, 6 \mathrm{H}) 1.06(\mathrm{~d}, \mathrm{~J}=6.9 \mathrm{~Hz}, 6 \mathrm{H}) .{ }^{13} \mathrm{C} \mathrm{NMR}\left(75 \mathrm{MHz}, \mathrm{CDCl}_{3}\right): \square$ $158.4,155.7,148.7,147.7,147.2$, 146.9, 135.8, 132.8, 131.7, 127.6, 124.8, 122.6, 121.1, 119.1, 60.1, 34.6, 27.8, 25.8, 25.6, 24.4, 23.7. HRMS (ESI') Calcd for $\mathrm{C}_{50} \mathrm{H}_{60} \mathrm{O}_{2} \mathrm{Br}_{2}$ [M+Na]: 897.2852. Found: 897.2906.

Bis(styrene) 26. A THF solution $(170 \mathrm{~mL})$ of dibromide 25, (6.57 g, $7.07 \mathrm{mmol})$ $\mathrm{Pd}\left(\mathrm{PPh}_{3}\right)_{4}(507 \mathrm{mg}, 0.49 \mathrm{mmol})$ and $p$-vinylphenylboronic acid (2.6 g, $\left.21 \mathrm{mmol}\right)$ was added to aqueous $\mathrm{K}_{2} \mathrm{CO}_{3}(35 \mathrm{~mL}, 1.0 \mathrm{M})$. The resultant mixture was heated to $70{ }^{\circ} \mathrm{C}$, with vigorous stirring, for 22 hours in a teflon-sealed bomb. After cooling, the mixture was diluted with water $(100 \mathrm{~mL})$ and ether $(200 \mathrm{~mL})$, and the organic phase separated. The aqueous layer was extracted with ether $(2 \times 100 \mathrm{~mL})$. All organic extracts were combined, washed with water, then brine, and dried over $\mathrm{MgSO}_{4}$. The crude material was triterated in hexane $(200 \mathrm{~mL})$ and filtered over celite to remove palladium salts. The product was purified via column chromatography on silica gel, eluting with hexane and methylene chloride (9:1) to afford a white powder (3.52 g, $3.8 \mathrm{mmol}, 54 \%$ yield). ${ }^{1} \mathrm{H}$ NMR (300 MHz, CDCl $)$ : $\square 8.08(\mathrm{~d}, \mathrm{~J}=1.8 \mathrm{~Hz}, 2 \mathrm{H}) 7.84(\mathrm{~s}, 2 \mathrm{H}) 7.72(\mathrm{~d}, \mathrm{~J}=8.3 \mathrm{~Hz}, 4 \mathrm{H})$ $7.61(\mathrm{dd}, \mathrm{J}=8.7 \mathrm{~Hz}, \mathrm{~J}=1.8 \mathrm{~Hz}, 2 \mathrm{H}) 7.54(\mathrm{~d}, \mathrm{~J}=8.3 \mathrm{~Hz}, 4 \mathrm{H}) 7.47$ (d, J = 8.7 Hz, 2H) $7.13(\mathrm{~d}, \mathrm{~J}=4.8 \mathrm{~Hz}, 4 \mathrm{H}) 6.79(\mathrm{dd}, \mathrm{J}=17.6 \mathrm{~Hz}, \mathrm{~J}=10.9 \mathrm{~Hz}, 2 \mathrm{H}) 5.84(\mathrm{~d}, \mathrm{~J}=17.6 \mathrm{~Hz}, 2 \mathrm{H})$ $5.29(\mathrm{~d}, \mathrm{~J}=10.9 \mathrm{~Hz}, 2 \mathrm{H}) 3.18(\mathrm{~s}, 6 \mathrm{H}) 2.94(\mathrm{~m}, 6 \mathrm{H}) 1.35(\mathrm{~d}, \mathrm{~J}=6.9 \mathrm{~Hz}, 12 \mathrm{H}) 1.24(\mathrm{~d}, \mathrm{~J}=$ $6.9 \mathrm{~Hz}, 6 \mathrm{H}) 1.17(\mathrm{~d}, \mathrm{~J}=6.9 \mathrm{~Hz}, 6 \mathrm{H}) 1.14(\mathrm{~d}, \mathrm{~J}=6.9 \mathrm{~Hz}, 6 \mathrm{H}) .{ }^{13} \mathrm{C} \mathrm{NMR}(75 \mathrm{MHz}$, $\left.\mathrm{CDCl}_{3}\right): \square 155.6,148.5,147.3,147.1,140.7,137.2,136.8,136.7,135.0,133.4,133.3$, 131.6, 130.8, 127.6, 127.0, 125.9, 125.8, 124.9, 121.0, 114.2, 70.5, 60.3, 34.6, 31.4, 31.2, 25.7, 25.6, 24.4, 23.7, 23.6. HRMS (ESI $)$ Calcd for $\mathrm{C}_{54} \mathrm{H}_{66} \mathrm{O}_{2}$ [M+Na]: 945.5581. Found: 945.5589 .

Polystyrene-supported chiral ligand 27. A $100 \mathrm{~mL}$ telfon-sealed bomb was charged with 26, (443 mg, $0.48 \mathrm{mmol})$ styrene, (3.5 g, $34 \mathrm{mmol})$ technical-grade divinylbenzene, (194 $\mathrm{mg}, 0.82 \mathrm{mmol})$ benzoyl peroxide $(50 \mathrm{mg})$ and poly(vinyl alcohol) $(50 \mathrm{mg})$ in a mixture of toluene and water $(6 \mathrm{~mL}: 50 \mathrm{~mL})$. The suspension was vigorously stirred at $80{ }^{\circ} \mathrm{C}$ for 16 hours. After cooling, a white powder was isolated by filtration, then washed with water, $(2 \times 50 \mathrm{~mL})$ THF, $(2 \times 50 \mathrm{~mL})$ methanol, $(3 \times 50 \mathrm{~mL})$ and pentane $(50 \mathrm{~mL})$. The resulting polymer sample was dried at $60{ }^{\circ} \mathrm{C}$ for $24 \mathrm{~h}$ to afford $3.45 \mathrm{~g}$ (87\% yield). This material ( $1.12 \mathrm{~g}$, theoretical loading: $0.28 \mathrm{mmol})$ was suspended in methylene chloride and treated with boron tribromide $(2.0 \mathrm{mmol})$ at $22{ }^{\circ} \mathrm{C}$, with vigorous agitation for $48 \mathrm{~h}$. To the mixture was added aqueous $\mathrm{HCl}(3 \%, 12 \mathrm{~mL})$, THF $(10 \mathrm{~mL})$ and methanol $(10 \mathrm{~mL})$, and the slurry agitated a subsequent $24 \mathrm{~h}$. After filtration, an offwhite polymer was obtained, washed with water $(10 \mathrm{~mL}), \mathrm{THF},(10 \mathrm{~mL})$ methanol, $(10$ $\mathrm{mL})$ and pentane $(10 \mathrm{~mL})$. The polymer sample was dried at $60{ }^{\circ} \mathrm{C}$ for $24 \mathrm{~h}$, to afford 
$1.03 \mathrm{~g}$ of the desired compound (87 \% yield). IR 3526 (s) 3051 (m) 3021 (m) 2962 (s) 2927 (s) 2871 (m) 1588 (w) 1511 (w) 1487 (m) 1064 (m).

Polystyrene-supported chiral Mo complex 29. Supported ligand $29(0.98 \mathrm{~g}$, theoretical loading: $0.12 \mathrm{mmol})$ was first suspended in THF $(10 \mathrm{~mL})$. Benzyl potassium $(41 \mathrm{mg}$, $0.32 \mathrm{mmol}$ ) was added to the mixture, and was allowed to stir for $2 \mathrm{~h}$ at $22{ }^{\circ} \mathrm{C}$. The resulting polymer was filtered, washed with THF $(2 \times 5 \mathrm{~mL})$ and pentane $(2 \times 5 \mathrm{~mL})$; it was subsequently dried in vacuo for $8 \mathrm{~h}$. The polymer was re-suspended in THF ( $5 \mathrm{~mL})$ and solid Mo triflate 28a (115 $\mathrm{mg}, 0.145 \mathrm{mmol}$ ) was added. The resulting mixture was gently agitated for $16 \mathrm{~h}$, filtered, washed with THF $(2 \times 5 \mathrm{~mL})$ and pentane $(2 \times 5 \mathrm{~mL})$ and dried in vacuo for $8 \mathrm{~h}$ to afford $0.88 \mathrm{~g}$ of $\mathbf{2 9}$ as a yellow-orange powder. Anal Calcd: $1.11 \%$ Mo; Found: $0.59 \%$ Mo; 53 \% loading, 0.062 mmol/g (Robertson-Microlit).

Polystyrene-supported chiral Mo complex 30. A suspension of potassium hexamethyldisilazide $(77 \mathrm{mg}, 0.36 \mathrm{mmol})$ and $27(1 \mathrm{~g}, 0.12 \mathrm{mmol} / \mathrm{g})$ in THF $(100 \mathrm{~mL})$ was agitated by slow rotation for $24 \mathrm{~h}$. The mixture was filtered, washed with THF ( $3 \mathrm{x}$ $20 \mathrm{~mL})$ and ether $(2 \times 25 \mathrm{~mL})$ and dried in vacuo to afford an orange-brown solid. To this solid was added THF $(15 \mathrm{~mL})$ and the requisite Mo triflate $(87 \mathrm{mg}, 0.12 \mathrm{mmol})$; the suspension was agitated for another 24 hours. The resulting product was filtered, washed with THF ( $3 \times 15 \mathrm{~mL}$, slightly yellow washings) and pentane $(4 \times 15 \mathrm{~mL})$, then dried in vacuo to deliver a brown powder, $1.0 \mathrm{~g}$. El Anal Calcd: $1.12 \%$ Mo; Found: $1.09 \%$ Mo; $97 \%$ loading, $0.119 \mathrm{mmol} / \mathrm{g}$ (Kolbe).

Representative asymmetric olefin metathesis with chiral Mo complex 29: In a dry box, to a solution of substrate $39(20.8 \mathrm{mg}, 0.100 \mathrm{mmol})$ in bezene $(1.0 \mathrm{~mL})$, supported catalyst $29(71.7 \mathrm{mg}, 0.00500 \mathrm{mmol})$ was added in a single portion. The reaction vessel was secured with a teflon-lined cap, and the mixture was agitated on an automated shaker plate for $2 \mathrm{~h}$. The resulting mixture was filtered through a pasteur pipette fitted with a cotton plug and concentrated in vacuo to afford cyclic siloxane $\mathbf{4 0}$ as a pale yellow oil (18.5 mg, $89 \%)$.

$(\boldsymbol{S})-\mathrm{Br}_{2}$ BiphenH $\mathrm{H}_{2}$ (47). A solution of bromine $(17.9 \mathrm{~g}, 112 \mathrm{mmol})$ in glacial acetic acid $(50 \mathrm{~mL})$ was added dropwise to a suspension of $(S)-\mathbf{4 5}{ }^{17}(18.1 \mathrm{~g}, 51 \mathrm{mmol})$ and sodium acetate $(16.9 \mathrm{~g}, 206 \mathrm{mmol})$ in glacial acetic acid $(450 \mathrm{~mL})$ over $30 \mathrm{~min}$, whereupon $\mathbf{4 5}$ slowly dissolved. The clear orange-yellow solution was allowed to stir for 15 min, after which ice-water $(1.0 \mathrm{~L})$ was added. The resulting suspension was allowed to stir $15 \mathrm{~min}$, then filtered to a light yellow solid. The solid was washed with cold water $(100 \mathrm{~mL})$, then taken up in ether $(200 \mathrm{~mL})$. Once in ether, the material was washed with cold water $(2 \times 50 \mathrm{~mL})$, then cold brine $(50 \mathrm{~mL})$. The organic phase was dried $\left(\mathrm{MgSO}_{4}\right)$ and concentrated in vacuo at $0{ }^{\circ} \mathrm{C}$. At this point, analysis of the ${ }^{1} \mathrm{H}$ NMR spectrum of the unpurified material indicated the presence of diquinone intermediate 46. ${ }^{1} \mathrm{H}$ NMR (300 $\left.\mathrm{MHz}, \mathrm{CDCl}_{3}\right)$ : $\square 6.90(\mathrm{~m}, 2 \mathrm{H}$, aryl $\mathrm{CH}) 1.93\left(\mathrm{~m}, 12 \mathrm{H}, \mathrm{CH}_{3}\right) 1.22\left(\mathrm{~m}, 18 \mathrm{H}, \mathrm{C}\left(\mathrm{CH}_{3}\right)_{3}\right) .{ }^{13} \mathrm{C}$ NMR (75 MHz, $\left.\mathrm{CDCl}_{3}\right)$ : $\square$ 152.7, 152.5, 152.0, 144.7, 144.5, 144.4, 142.4, 133.0, 60.6, $34.3,29.8,28.9,16.9$. Solid 46 will rearrange over $5-21$ days to the desired dibromide 47. ${ }^{1} \mathrm{H}$ NMR (300 MHz, CDCl $)$ : $\square 7.32(\mathrm{~s}, 2 \mathrm{H}$, aryl CH) $5.01(\mathrm{~s}, 2 \mathrm{H}, \mathrm{OH}) 4.57(\mathrm{~s}, 4 \mathrm{H}$, 
$\left.\mathrm{CH}_{2} \mathrm{Br}\right) 1.94\left(\mathrm{~s}, 6 \mathrm{H}, \mathrm{CH}_{3}\right) 1.39\left(\mathrm{~s}, 18 \mathrm{H}, \mathrm{C}\left(\mathrm{CH}_{3}\right)_{3}\right) .{ }^{13} \mathrm{C} \mathrm{NMR}\left(75 \mathrm{MHz}, \mathrm{CDCl}_{3}\right): 152.9$, $135.8,134.6,130.1,128.1,121.1,34.734 .129 .415 .2$.

Norbornylmethylene magnesium bromide, 48. Dicyclopentadiene, (30 mL, 224 mmol), allyl bromide (46 mL, $537 \mathrm{mmol}$ ) and hydroquinone $(150 \mathrm{mg}$ ) were heated to 170 ${ }^{\circ} \mathrm{C}$ in a Teflon-valve sealed bomb for 20 hours. After cooling, excess allyl bromide was removed by heating the mixture to $100{ }^{\circ} \mathrm{C}$. The remaining oil was purified distillation at reduced pressure $\left(40{ }^{\circ} \mathrm{C}, 300 \mathrm{mTorr}\right)$ to afford $60 \mathrm{~g}(71 \%)$ of clear, colourless oil: mixture of exo and endo isomers. ${ }^{1} \mathrm{H}$ NMR (500 MHz, $\left.\mathrm{C}_{6} \mathrm{D}_{6}\right)$ : MAJOR ISOMER (endo) प6.22 (m, 1H, H3) $6.01(\mathrm{~m}, 1 \mathrm{H}, \mathrm{H} 2) 3.23(\mathrm{dd}, 1 \mathrm{H}, \mathrm{J}=6.9 \mathrm{~Hz}, 9.6 \mathrm{~Hz}, \mathrm{H} 8) 3.06(\mathrm{dd}, 1 \mathrm{H}$, $\mathrm{J}=6.9 \mathrm{~Hz}, 9.6 \mathrm{~Hz}, \mathrm{H} 8) 3.001$ (s, 1H, H4) 2.89 (s, 1H, H1) 2.54 (m, 1H, H5) 1.96 (m, 1H, $\left.\mathrm{H}_{\text {exo }}\right) 1.50(\mathrm{~m}, 1 \mathrm{H}, \mathrm{H} 7) 1.31(\mathrm{~d}, 1 \mathrm{H}, \mathrm{J}=8.2 \mathrm{~Hz}, \mathrm{H} 7) 0.60\left(\mathrm{~m}, 1 \mathrm{H}, \mathrm{H} 6_{\text {endo }}\right) .{ }^{13} \mathrm{C} \mathrm{NMR}(100$ $\left.\mathrm{MHz}, \mathrm{CDCl}_{3}\right): \square 138.2,131.6,49.6,45.4$ 43.1, 42.1, 38.3, 32.7. An ether solution of norbornylmethylene bromide $(6.25 \mathrm{~g}, 33 \mathrm{mmol})$ was added dropwise to a slurry of magnesium sand ( $2 \mathrm{~g}, 83 \mathrm{mmol})$ in ether. The mixture proceeded to auto-reflux for 30 minutes, after which it was filtered over celite and titrated against cumylphenol with 1,10-phenanthrolein as indicator.

(S)-(Norb) $)_{2}$ BiphenH $\mathrm{H}_{2}$ 49. ( $S$ )-Br $\mathrm{BriphenH}_{2}, 47,(2.3 \mathrm{~g}, 4.5 \mathrm{mmol})$ in THF was added dropwise to norbornylmethylene magnesium bromide $(19 \mathrm{~mL}, 0.95 \mathrm{M})$ at $-30{ }^{\circ} \mathrm{C}$, to produce a mild exotherm. After the solution was allowed to stir for $2 \mathrm{~h}$, the white suspension was quenched by addition of methanol. After warming to room temperature, water was added and the mixture washed three times with ether $(200 \mathrm{~mL})$. The organic layers were combined, washed with $\mathrm{NH}_{4} \mathrm{Cl}_{(\mathrm{aq})}$, dried over $\mathrm{MgSO}_{4}$ and concentrated in vacuo to a cloudy oil. Residual water was removed by lyophilization with benzene, followed by dissolution in THF and storage over sieves for 24 hours. The material was then decanted and reconcentrated to afford a viscous oil $(2.4 \mathrm{~g}, 93 \%)$. ${ }^{1} \mathrm{H}$ NMR (500 $\left.\mathrm{MHz}, \mathrm{C}_{6} \mathrm{D}_{6}\right)$ : $7.35(\mathrm{~s}, 2 \mathrm{H}$, aryl CH) $6.10(\mathrm{~m}, 1 \mathrm{H}) 6.06(\mathrm{~m}, 1 \mathrm{H}) 5.93(\mathrm{~m}, 2 \mathrm{H}) 4.88(\mathrm{~s}, 2 \mathrm{H}$, OH) $2.74-2.5$ (br m, 8H) $1.95\left(\mathrm{~s}, 3 \mathrm{H}, \mathbf{C H}_{3}\right) 1.94\left(\mathrm{~s}, 3 \mathrm{H}, \mathrm{CH}_{3}\right) 1.85-1.80$ (br m, 3H) $1.56\left(\mathrm{~s}, 18 \mathrm{H}, \mathrm{C}\left(\mathrm{CH}_{3}\right)_{3}\right) 1.53(\mathrm{~m}, 2 \mathrm{H}) 1.42(\mathrm{~m} 4 \mathrm{H}) 1.17(\mathrm{~m}, 2 \mathrm{H}) 1.13(\mathrm{~m}, 2 \mathrm{H}) 0.54(\mathrm{~m}$, 2H). ${ }^{13} \mathrm{C}$ NMR (100 MHz, $\left.\mathrm{CDCl}_{3}\right)$ : $\square$ 150.9, 137.4, 137.1, 136.4, 134.0, 133.6, 132.6, $132.5,132.4,128.7,128.5,127.9,121.7,50.0,49.9,45.9,45.8,42.9,39.3,36.8,34.9$, $34.2,33.5,32.9,32.8,29.8,15.6$.

1,4,4a,5,8,8a-hexahydro-1,4,5,8-exo/endo-dimethanonapthalene (50). A Teflonsealed glass bomb was charged with nobornylene, 51, (36 mL, $384 \mathrm{mmol})$ dicyclopentadiene $(20 \mathrm{~mL}, 164 \mathrm{mml})$ and hydroquinone $(115 \mathrm{mg}, 1.04 \mathrm{mmol})$ and heated to $180{ }^{\circ} \mathrm{C}$. After 72 hours, the vessel was cooled to room temperature and purified by fractional distillation at $60 \mathrm{mTorr}$ with slight heating. The first fraction recovered $(25-$ $\left.30{ }^{\circ} \mathrm{C}\right)$ is excess norbornylene $(12 \mathrm{~g}, 39 \%)$ and the second fraction $\left(30-35^{\circ} \mathrm{C}\right)$ is the desired product $(14 \mathrm{~g}, 30 \%)$. The product was redistilled from sodium prior to use. ${ }^{1} \mathrm{H}$ NMR (500 MHz, $\left.\mathrm{C}_{6} \mathrm{D}_{6}\right)$ : exo/endo isomer: $\square 6.20,(\mathrm{t}, 2 \mathrm{H}, \mathrm{J}=1.5 \mathrm{~Hz}, \mathrm{CH}) 5.91,(\mathrm{t}, 2 \mathrm{H}, \mathrm{J}=$ $1.5 \mathrm{~Hz}, \mathrm{CH}) 2.61(\mathrm{~d}, 1 \mathrm{H}, \mathrm{J}=8.6 \mathrm{~Hz}, \mathrm{CH}) 2.57(\mathrm{~m}, 2 \mathrm{H}) 2.44(\mathrm{~m}, 2 \mathrm{H}) 2.14(\mathrm{~m}, 2 \mathrm{H}) 1.69$ $(\mathrm{m}, 1 \mathrm{H}) 1.42(\mathrm{~m}, 1 \mathrm{H}) 1.16(\mathrm{~d}, 1 \mathrm{H}, \mathrm{J}=8.9 \mathrm{~Hz})$. endo/endo isomer: $\square 5.23(\mathrm{~m}, 4 \mathrm{H}) 2.54$ $(\mathrm{m}, 2 \mathrm{H}) 2.5(\mathrm{~m}, 4 \mathrm{H}) 1.61(\mathrm{~d}, \mathrm{~J}=7.0 \mathrm{~Hz}, 1 \mathrm{H}) .{ }^{13} \mathrm{C} \mathrm{NMR}\left(100 \mathrm{MHz}, \mathrm{C}_{6} \mathrm{D}_{6}\right): 131.6,55.8$, $44.9,43.2$. 
Polynorbornyl-supported chiral Mo complex 53a. Potassium hydride (50 $\mathrm{mg}, 1.3$ mmol) was added to a solution of $47(230 \mathrm{mg}, 0.40 \mathrm{mmol})$ in THF $(25 \mathrm{~mL})$ at room temperature. After 3 hours, the ligand solution was filted over celite and added to a solution of $50(1.78 \mathrm{~g}, 11.2 \mathrm{mmol})$ in THF $(25 \mathrm{~mL})$ which had been cooled to $-35{ }^{\circ} \mathrm{C}$ during the previous $3 \mathrm{~h}$. With vigorous stirring, a THF $(3 \mathrm{~mL})$ solution of the the requisite Mo triflate $\left(\left(\mathrm{Ar}_{\mathrm{Pr}} \mathrm{N}\right) \mathrm{Mo}\left(\mathrm{CHCMe}_{2} \mathrm{Ph}\right)(\mathrm{OTf})_{2} \bullet \mathrm{dme} ; 322 \mathrm{mg}, 0.40 \mathrm{mmol}\right)$ was added to the mixture. After approximately $15 \mathrm{~min}$, the clear, deep-red mixture developed a jello-like consistency. The mixture was agitated for $12 \mathrm{~h}$, and was then allowed to warm to room temperature. The material was gently pounded in a mortar and pestle, filtered over a coarse frit, and washed with toluene $(50 \mathrm{~mL})$, pentane $(50 \mathrm{~mL})$ and ether $(3 \mathrm{x} 20 \mathrm{~mL})$. After drying in vacuo, $2.12 \mathrm{~g}$ of an orange-tan solid was obtained.

Representative procedure for synthesis of lower cross-linking polynorbornyls. Polynorbornyl-supported chiral Mo complex 53d. Potassium hydride $(20 \mathrm{mg}, 0.50$ mmol) was added to a solution of $47(94 \mathrm{mg}, 0.167 \mathrm{mmol})$ in THF $(5 \mathrm{~mL})$ at room temperature. After $3 \mathrm{~h}$, the ligand solution was filtered over celite and added to a solution of norbornylene, 51, (1.0 g, $10.6 \mathrm{mmol})$ and $\mathbf{5 0}(127 \mathrm{mg}, 0.8 \mathrm{mmol})$ in THF $(50 \mathrm{~mL})$ which had been cooled to $-35^{\circ} \mathrm{C}$ during the previous $3 \mathrm{~h}$. With vigorous stirring, a THF $(3 \mathrm{~mL})$ solution of $\left(\mathrm{Ar}_{\mathrm{Pr}} \mathrm{N}\right) \mathrm{Mo}\left(\mathrm{CHCMe}_{2} \mathrm{Ph}\right)(\mathrm{OTf})_{2} \bullet \mathrm{dme}(132 \mathrm{mg}, 0.167 \mathrm{mmol})$ was added to the mixture. After approximately $15 \mathrm{~min}$, the clear, deep-red mixture developed a jello-like consistency. The mixture was allowed to stir overnight and then allowed to warm to room temperature. The material was gently pounded in a mortar and pestle, filtered over a coarse frit, and washed with toluene $(20 \mathrm{~mL})$, pentane $(20 \mathrm{~mL})$ and ether ( 3 x $20 \mathrm{~mL}$ ). After drying in vacuo, $700 \mathrm{mg}$ of a bright-orange solid was obtained. El Anal Calcd: 1.39 \% Mo; Found: 0.72 (Kölbe, 0.075 mmol/g); 0.66 (Robertson-Microlit, $0.069 \mathrm{mmol} / \mathrm{g})$.

Polynorbornyl-supported chiral Mo complex 54. Potassium hydride ( $22 \mathrm{mg}, 0.555$ mmol) was added to a solution of $47(105 \mathrm{mg}, 0.185 \mathrm{mmol})$ in THF $(5 \mathrm{~mL})$ at room temperature. After 3 hours, the ligand solution was filted over celite and added to a solution of norbornylene, 51, (1.15 g, $12.2 \mathrm{mmol})$ and $\mathbf{5 0}(150 \mathrm{mg}, 0.924 \mathrm{mmol})$ in THF $(50 \mathrm{~mL})$ which had been cooled to $-35{ }^{\circ} \mathrm{C}$ during the previous $3 \mathrm{~h}$. With vigorous stirring, a THF $(3 \mathrm{~mL})$ solution of $\left(\mathrm{Ar}_{\mathrm{Cl}} \mathrm{N}\right) \mathrm{Mo}(\mathrm{CH} t \mathrm{Bu})(\mathrm{OTf})_{2} \bullet \mathrm{dme}(143 \mathrm{mg}, 0.185 \mathrm{mmol})$ was added to the mixture. After approximately $5 \mathrm{~min}$, the clear, deep-red mixture developed a jello-like consistency. The mixture was allowed to stir overnight and was then warmed to room temperature. The material was gently pounded in a mortar and pestle, filtered over a coarse frit, and washed with toluene $(20 \mathrm{~mL})$, pentane $(20 \mathrm{~mL})$ and ether $(3 \times 20 \mathrm{~mL})$. After drying in vacuo, $1.2 \mathrm{~g}$ of a dark-brown solid was obtained. El Anal Calcd: $1.21 \%$ Mo; Found: 0.78 (Kölbe, 0.081 mmol/g); 0.68 (Robertson-Microlit, $0.071 \mathrm{mmol} / \mathrm{g})$.

Polynorbornyl-supported chiral Mo complex 55. Potassium hydride (39 $\mathrm{mg}, 0.96$ mmol) was added to a solution of $47(180 \mathrm{mg}, 0.32 \mathrm{mmol})$ in THF $(10 \mathrm{~mL})$ at room temperature. After $3 \mathrm{~h}$, the ligand solution was filted over celite and added to a solution of norbornylene, 51, (1.95 g, $20.7 \mathrm{mmol})$ and $\mathbf{5 0}(250 \mathrm{mg}, 1.58 \mathrm{mmol})$ in THF (50 mL) 
which had been cooled to $-35^{\circ} \mathrm{C}$ during the previous $3 \mathrm{~h}$. With vigorous stirring, a THF $(3 \mathrm{~mL})$ solution of the required Mo triflate $\left((\mathrm{AdN}) \mathrm{Mo}(\mathrm{CHNp})(\mathrm{OTf})_{2} \bullet \mathrm{dme} ; 245 \mathrm{mg}, 0.32\right.$ mmol) was added to the mixture. After approximately 5 minutes, the clear, deep-red mixture developed a jello-like consistency. The mixture was allowed to stir for $12 \mathrm{~h}$, warming to room temperature. The resulting material was gently pounded in a mortar and pestle, filtered over a coarse frit, and washed with toluene $(20 \mathrm{~mL})$, pentane $(20 \mathrm{~mL})$ and ether $(3 \times 20 \mathrm{~mL})$. After drying in vacuo, $2.5 \mathrm{~g}$ of a bright-orange solid was obtained. El Anal Calcd: 1.23 \% Mo; Found: 0.85 (Kölbe, $0.089 \mathrm{mmol} / \mathrm{g}$ ); 0.78 (Robertson-Microlit, $0.081 \mathrm{mmol} / \mathrm{g}$ ).

\section{References:}

(1) Oskam, J. H.; Fox, H. H.; Yap, K. B.; McConville, D. H.; O'Dell, R.; Lichtenstein, B. J.; Schrock, R. R. J. Organomet. Chem. 1993, 459, 185.

(2) Schrock, R. R.; Jamieson, J. Y.; Dolman, S. J.; Miller, S. A.; Bonitatebus, P. J.; Hoveyda, A. H. Organometallics 2002, 21, 409.

(3) Hultzsch, K. C.; Jernelius, J. A.; Hoveyda, A. H.; Schrock, R. R. Angew. Chem. Int. Ed. 2002, 41, 589.

(4) Alexander, J. B.; La, D. S.; Cefalo, D. R.; Hoveyda, A. H.; Schrock, R. R. J. Am. Chem. Soc. 1998, 120, 4041.

(5) La, D. S.; Alexander, J. B.; Cefalo, D. R.; Graf, D. D.; Hoveyda, A. H.; Schrock, R. R. J. Am. Chem. Soc. 1998, 120, 9720.

(6) La, D. S.; Ford, G. J.; Sattely, E. S.; Bonitatebus, P. J.; Schrock, R. R.; Hoveyda, A. H. J. Am. Chem. Soc. 1999, 123, 11603.

(7) La, D. S.; Sattely, E. S.; Ford, J. G.; Schrock, R. R.; Hoveyda, A. H. J. Am. Chem. Soc. 2001, 123, 7767.

(8) Dolman, S. J.; Sattely, E. S.; Hoveyda, A. H.; Schrock, R. R. J. Am. Chem. Soc. 2002, $124,6991$.

(9) Dolman, S. J.; Schrock, R. R.; Hoveyda, A. H. Org. Lett. 2003, 5, 4899.

(10) Tsang, W. C. P.; Jernelius, J. A.; Cortez, G. A.; Weatherhead, G. S.; Schrock, R. R.; Hoveyda, A. H. J. Am. Chem. Soc. 2003, 125, 2591.

(11) Cefalo, D. R.; Kiely, A. F.; Wurcher, M.; Jamieson, J. Y.; Schrock, R. R.; Hoveyda, A. H. J. Am. Chem. Soc. 2001, 123, 3139.

(12) Zhu, S. S.; Cefalo, D. R.; La, D. S.; Jamieson, J. Y.; Davis, W. M.; Hoveyda, A. H.; Schrock, R. R. J. Am. Chem. Soc. 1999, 121, 8251.

(13) Teng, X.; Cefalo, D. R.; Schrock, R. R.; Hoveyda, A. H. J. Am. Chem. Soc. 2002, $124,10779$.

(14) Weatherhead, G. S.; Ford, J. G.; Alexenian, E. J.; Schrock, R. R.; Hoveyda, A. H. J. Am. Chem. Soc. 2000, 122, 1828.

(15) Weatherhead, G. S.; Houser, J. H.; Ford, J. G.; Jamieson, J. Y.; Schrock, R. R.; Hoveyda, A. H. Tet. Lett. 2000, 41, 9553.

(16) Kiely, A. F.; Jernelius, J. A.; Schrock, R. R.; Hoveyda, A. H. J. Am. Chem. Soc. 2002, 124, 2868.

(17) Alexander, J. B.; Schrock, R. R.; Davis, W. M.; Hultzsch, K. C.; Hoveyda, A. H. Organometallics 2000, 19, 3700. 